\title{
AN EXPERIMENTAL STUDY TO INVESTIGATE THE RHEOLOGICAL PROPERTIES OF FRESH SCC USING NEW CONCRETE SHEAR BOX
}

\author{
Girish. S', Ajay. N², Ashwin. M. Joshi' ${ }^{3}$, Namratha Bharadwaj4 \\ ${ }^{1}$ Professor, Department of Civil Engineering, B. M. S. College of Engineering, Bangalore - 560 019, India \\ ${ }^{2}$ Research Scholar, B. M. S. College of Engineering, Bangalore - 560 019, India \\ ${ }^{3}$ Research Scholar, B. M. S. College of Engineering, Bangalore - 560 019, India \\ ${ }^{4}$ Assistant Professor, B. M. S. College of Architecture, Bangalore - 560 019, India
}

\begin{abstract}
Flow characterization and controlling fresh property of SCC is most critical. Even slight variations in ingredients can have adverse effect on fresh properties; strength and durability of hardened concrete. The material science approach to study rheological properties is essential in order to overcome the paucity posed while characterizing mixes by empirical methods such as the slump flow test.

In the present work, the Bingham parameters of SCC were assessed by using the new concrete shear box. The mixes were designed considering volume of paste based on absolute volume concept. Three different volumes of pastes (0.38, 0.40 and 0.42) with water contents of 170 and $190 \mathrm{lt} / \mathrm{m}^{3}$ and cement contents of 300 and $450 \mathrm{~kg} / \mathrm{m}^{3}$ along with slag as filler was used. A unique test procedure was followed, by applying low normal stresses of 0.10, 0.20 and 0.30 MPa with three different displacement rates of 1 , 5 and $15 \mathrm{~mm} / \mathrm{min}$ under static condition. The results indicate that the new concrete shear box shall effectively put to use, as an additional tool for evaluating the rheological properties of SCC viz., yield stress and plastic viscosity.
\end{abstract}

Keywords: - Slump test, Rheology, SCC, Yield Stress and Plastic Viscosity, New Concrete Shear Box, Bingham Model $* * *$

\section{INTRODUCTION}

Concrete as a building material has created revolution in construction industry. The present day architectural requirements, demand for high structural performance resulted in the use of high percentage of reinforcements in structural elements with complex shapes. In addition, durability, an important aspect of any structure, is directly related to the degree and quality of consolidation achieved. To overcome the problems of concreting in areas congested with reinforcement and to improve the durability and speed of construction, utilization of SelfCompacting Concrete (SCC) is gaining importance. SCC is different from conventional vibrated concrete (CVC) with higher pow-der content and having wide range of filler materials. In addition, the use of superplasticizer (SP) influences the fresh properties depending on its base, dosage and time of mixing, to name a few. Sometimes SCC also incorporates viscosity-modifying admixture (VMA). The use of such variety of materials in preparation of SCC mixes mandates scientific approach to study on fresh properties since it is important, critical and vulnerable [1].
There are many guidelines proposed [2] by institutes and organizations to characterize the SCC mixes by several test methods [3]. However SCC is more sensitive to the changes in the material properties than that of CVC. Amongst test methods, the slump test in more commonly used and is universally accepted as a measure of workability for all type of mixes from conventional concrete to high performance concrete mixes, like SCC. The slump test is a static test, not a dynamic one. Though the test is simple, it is quite incapable of differentiating two concretes mixes of different composition. Fig-ure 1 shows two mixes having the same slump flow despite having different mix pro-portions. The two concrete mixes may behave differently during placement though their slump flow values may be the same. Concrete flow property cannot be characterized by empirical tests which are generally single parameter tests. The slump flow test does not indicate variations in mix proportioning which is, in fact, very crucial for concrete mixes; especially for SCC mixes since a small variation in mix proportioning can lead to problems with workability affecting the hardened properties. 


\section{RHEOLOGY OF SCC}

Rheology is a scientific approach, which studies flow and deformation of material under the influence of stresses [8]. Often, it is used to describe the flow characteristics of complex fluids with respect to shear stress and shear rate [9]. Rheology of Fluids is established and widely accepted. Basically, fluids are classified as Newtonian and Non-Newtonian fluids and fresh concrete is assumed as a Non-Newtonian Bingham fluid [10]. Fresh concrete is examined considering it as suspension of granular aggregates of varying sizes in a viscous medium viz., cement paste [10].

In rheological approach, the flow of concrete is characterized by minimum two properties; viz, yield $\operatorname{stress}(\square \square)$ and plastic viscosity $(\square)[10,11,12]$. The yield stress is related to concrete slump; it is defined as "the minimum force required to break down the structure of concrete and initiate flow". The plastic viscosity describes the resistance to flow, once concrete is flowing and it is related to the time of concrete slumping (speed of the flow) during the test [12]. Both values are necessary to understand how the processing parameters are linked to the rheological behavior of concrete. These rheological properties are measured by constitutive equations or rheometers. Based on shear stress and shear rate, constitutive equations (about six) are developed to characterize concrete flow [12]. The general form of the equations are simply represented graphically which are shown in Figure 2.

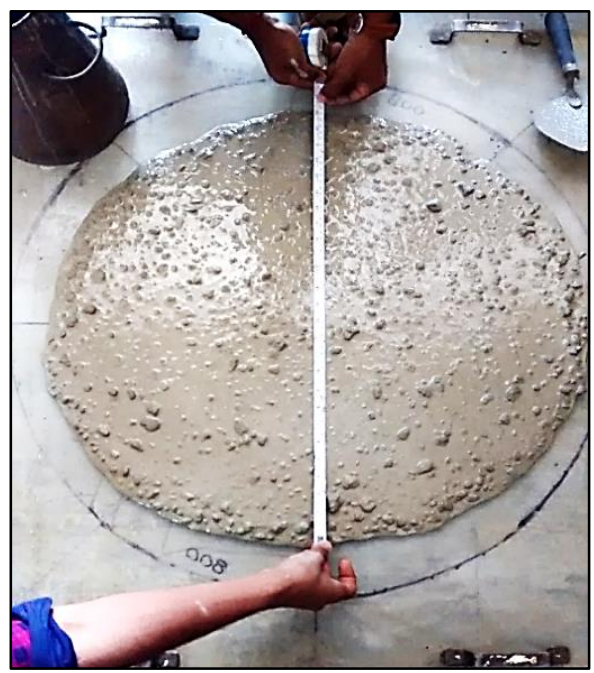

(a) Powder $=550 \mathrm{~kg} / \mathrm{m}^{3} ;$ Water $=180 \mathrm{lit} / \mathrm{m}^{3} ; \mathrm{SP}=0.5 \%$; Slump flow $=700 \mathrm{~mm}(\mathrm{avg})$.

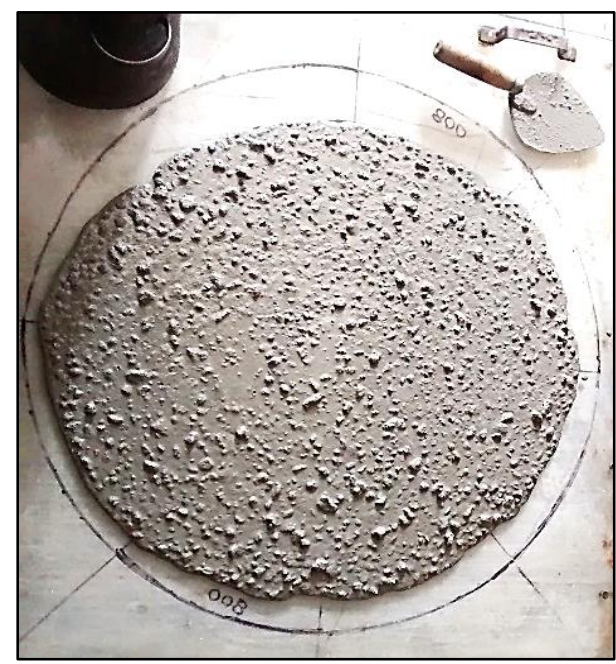

(b) Powder $=580 \mathrm{~kg} / \mathrm{m}^{3}$; Water $=190 \mathrm{lit} / \mathrm{m}^{3} ; \mathrm{SP}=0.5 \%$; Slump Flow $=700 \mathrm{~mm}(\mathrm{avg})$.

Fig 1: Different SCC mixes showing same slump flow with constant dosage of superplasticizer

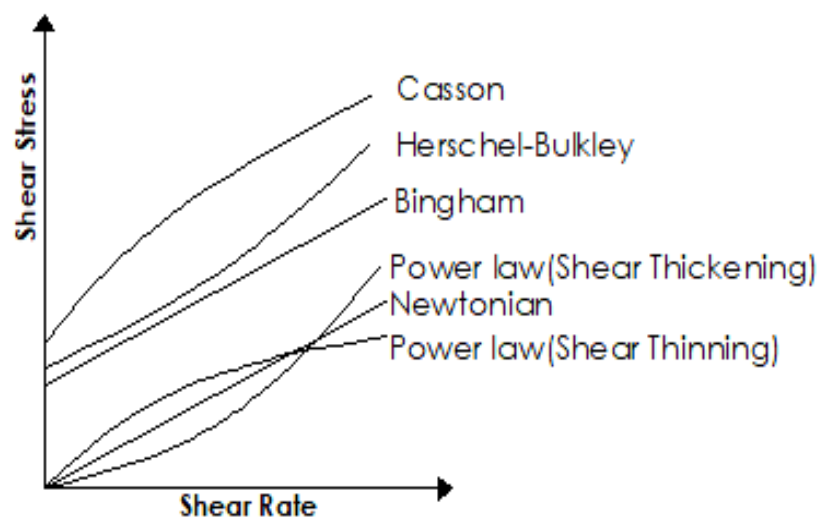

Fig 2: Basic Constitutive Relationships for Flow [12]

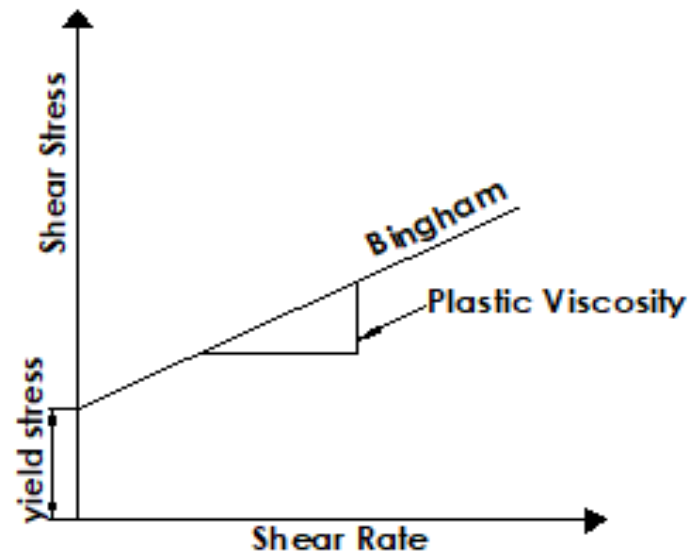

Fig 3: Bingham model [12] 
The rheology of fresh concrete can be measured by relationship between shear stress and shear rate through flow curves. Amongst these, most of researchers agreed in using Bingham equation for flow characterization of concrete [13]. When compared to Newtonian equation, the Bingham equation (Figure 3) incorporates $\square \square \square$ and $\square \square[12,13]$. The general form of Bingham equation (Equ 1) is given by

$$
\tau=\tau_{o}+\mu \gamma \quad(\text { Equ. 1) }
$$

Where; $\tau=$ shear stress $(\mathrm{Pa}) ; \tau_{o}=$ yield stress $(\mathrm{Pa}) ; \mu=$ plastic viscosity (Pa-s) and $\gamma=$ shear rate $(1 / \mathrm{s})$.

Rheometer(s) is a device used to measure shear stress at varying shear rates from its fundamental properties [9] and using these values one can predict behavior of concrete or find rheological properties. Rotational type rheometers are used for concrete typically due to precision in measuring rheological parameters in fundamental units as compared to other types of rheometers.. Basically the stimulus provided by rheometers to sample is dynamic in nature and generally measures dynamic yield stress and concrete is subjected to very high shear rates. In field, at the time of placing, concrete will not experience such high shear rates. Eachrheometer has it is own limitations such as geometry restrictions or tendency to cause segregation; which we must overcome prior towidespread use [12]. The values of $\square \square \square$ and $\square$ compiled by Ferraris using different types of rheometers for the same concrete mix shows disagreement in measured values [17]. Additionally, Andraz et.al. study [18] also shows different absolute values for yield stress and plastic viscosity amongst rheometers.

In order to overcome the some of the limitations of rheometers, there is need a study "the flow" of fresh concrete (SCC) adopting Bingham model by using new concrete shear box which itself employs a unique new procedure to determine the Bingham parameters under static condition.

\section{CONCRETE SHEAR BOX}

Based on the Herschel, Pisapia and L'Hermite [19] works, Girish. S and R. V. Ranganath [20-26] designed and developed an instrument called the concrete shear box'. The basic working principle of direct shear box is alike; with additional features relevant to test fresh concrete. It has two halves with lower half fixed and the upper moves when a horizontal force is applied along with a normal stress during testing. The schematic diagram of the concrete shear box is shown in Figure 4.
This new tool is capable of applying a displacement rate that range from 1 to $100 \mathrm{~mm} / \mathrm{min}$ and normal stresses up to 3.0 MPaalong with stress regulator through a pneumatic actuator. The values are recorded using a servo-controlled electronic data acquisition system. The instrument has been designed to test the sample size of $150 \mathrm{~mm}$ and coarse aggregate of maximum size $25 \mathrm{~mm}$.

Figure 5 shows the new concrete shear box used. The key factor being its ability to operate at low shear rate; which is synonymous with field condition concrete experiences and the static condition of the test.

\section{EXPERIMENTAL WORK}

\subsection{Materials}

Ordinary Portland cement (OPC - 53 grade) complying IS 12269-2013 and having specific gravity 3.13 and Blaine fineness $260 \mathrm{~m}^{2} / \mathrm{kg}$ was used. Natural River sand (Confirming to Zone II as Fine Aggregate); crushed angular granite (as coarse aggregate) of size $20 \mathrm{~mm}(70 \%)$ and $12.5 \mathrm{~mm}(30 \%)$. The bulk specific gravities of fine and coarse aggregate were 2.6 and absorption values were $2.0 \%$ and $0.9 \%$ respectively. Filler was Ground Granulated Blast-Furnace Slag (GGBS) conforming to IS 12089 - 1987 and the specific gravity and Blaine fineness values were 2.9 and $425 \mathrm{~m}^{2} / \mathrm{kg}$. The polycarboxylic ether based superplasticizer was used as high range water reducer confirming to IS 9103 and IS 2645 standards.

\subsection{Methodology}

Based on the previous study in the same laboratory and published literature [27, 28], SCC mixes were developed by a new mix design by absolute volume concept starting with a volume of paste (Vp) [29]. The method developed by Girish [29] based on extensive trials is unique and simple. SCC mixes can be developed by one-go approach, that is, the mixes can be developed even with single trials. In this method volume of paste is chosen based on the type of aggregates, required slump flow and the mixes are proportion based on absolute volume. The volume of paste can be in the range of 0.37 to 0.43 . Higher volume of paste when flow required is more, and in cases of unfavorable quality of coarse aggregate like crushed angular and elongated. The volume fraction of fine aggregate and coarse aggregate is then decided either by trials or based on the published literature [27,28]. The SP dosage (optimum value) was established through Marsh cone test for the chosen powder and water content.

In the present work, 12 different SCC mixes were developed with varying paste contents $(0.38,0.40$ and 0.42$)$, water contents $\left(170\right.$ and $\left.190 \mathrm{lt} / \mathrm{m}^{3}\right)$ and cement contents (300 and $\left.450 \mathrm{~kg} / \mathrm{m}^{3}\right)$. The $\mathrm{w} / \mathrm{c}$ ratio ranged from 0.37 to 0.63 . The 
proportion of coarse aggregate to fine aggregate was taken as 40:60. This was chosen based on the study conducted in the same laboratory. Further coarse aggregate chosen were a combination of aggregates of size $20 \mathrm{~mm}$ down and $12.5 \mathrm{~mm}$ down in the ratio $30: 70$ respectively.

For different mixes, Marsh cone test was conducted for each of the chosen powder and water contents to arrive at the optimum dosage and the same was kept constant throughout the experiments. Viscosity modifying admixture has not been employed in the current study since all the mixes were developed under laboratorycontrolled conditions. Table 1 show the mix proportion used in this study. The developed mixes were tested for rheological properties under three different displacement rates $(1,5,15 \mathrm{~mm} / \mathrm{min})$ with three normal stresses $(0.10$, $0.20,0.30 \mathrm{MPa})$. The numbers of trials were exhaustive and totals 108 .

Slump flow, J-ring and V Funnel tests were conducted based on EFNARC guidelines [30] and ACI code [2] to ascertain the fresh properties requirements of filling ability, passing ability and segregation resistance. The detailed fresh properties result are not shown here, but discussion on flowability is discussed later and barring few mixes all the mixes with different paste and cement contents satisfied the EFNARC guidelines [30]. The method of mixing is very important when SP is used which can influence in enhancing the workability of SCC. It should be ensured that the mixing energy is sufficient to evenly distribute water and SP and take advantage of adsorption of molecules of poly-carboxylate ether or acrylic copolymer based SP. The SP having longer lateral chains of molecules require mixing of water in installments. A modified mixing procedure based on number of trials on SCC mixes were developed earlier by Girish (29) and a detailed discussion is given elsewhere [29]. In the modified procedure the mixing sequence of ingredients are different and initially major portion of water along with superplasticizer is considered before mixing the other ingredients. Finally, remaining water and superplasticizer is added in installments.

\subsection{Rheological Properties of Fresh Concrete:}

\section{Procedure}

The step by step procedure to find rheological properties of SCC is given below and shown graphically in Figure 6.A unique procedure followed to find the Bingham parameter (Figure 6) of fresh concrete is based on published literature [26]. A brief description of procedure for one of the mixes (Mix S1) studied is as follows;

\section{Step - 1}

Place fresh concrete in new concrete shear box mold after through mixing and specific normal stress and displacement rates were applied. Initial testing Shear stress starts decreasing after reaching the peak value (point of dilatancy) or becomes constant, and this marks the end for test trial. Graph of shear stress versus shear strain was plotted, as indicated in Figure 7 representing such behavior. The maximum or peak shear stress for a certain displacement rate and normal stress was found. Further, keeping the normal stress constant, trials were repeated for different displacement rates and in each trials, maximum shear stress were found. The obtained peak shear stress value are tabulated in Table 2 .

\section{Step - 2}

Using values of the maximum shear stress (Table 2) obtained in step 1, straight line fits are derived between the maximum or peak shear stress and normal stresses for each of the displacement rates. Maximum shear stress is obtained at zero normal stress (ZNS) for different displacement rates individually after extrapolating the line to the readings on the ordinate. The intercept on axis representing the shear stress gives the yield stress of concrete (at ZNS) (Figure 7). It is interesting to note that the shear stress at zero normal stress can be obtained even though the experiment cannot be carried out at without applying normal stress. L'Hermite has termed this as intrinsic shear strength (when the normal stress is zero) and can be consider as yield stress of concrete at ZNS.

\section{Step - 3}

Further, yield stress at ZNS (Table 3) obtained in the previous step are plotted against different displacement rates and the straight line fits are plotted. The intercept of the trendline on the ordinate gives the yield stress and its slope is plastic viscosity of the concrete, similar to the Bingham parameters (Figure 8). It is to be noted that the yield stress value obtained corresponds to zero displacement rate. This procedure is unique, since yield stress and plastic viscosity corresponds to zero displacement rates after obtaining the peak shear stress at ZNS; their values are tabulated in Table 4.

\section{RESULTS AND DISCUSSION}

The values of peak shear stress obtained for different values of normal stress and displacement rate for each of the mixes has been tabulated in Table 2 . It is seen, for a given mix with a particular displacement rate, the normal stress and peak shear is directly proportional. This may be due to with increased normal stress, the particles get closer causing interlocking of aggregates; leading to increased resistance, higher peak values. 
This phenomenon remains true for all mix proportions under all displacement rates. Also, for the majority of mixes, results show that for a given mix subjected to a particular normal stress, as the displacement rate increases, the peak shear stress decreases. It is likely that the chosen value of displacement rate influences the results and hence the Bingham parameters. Table 3 shows values of shear stress at ZNS for various displacement rates. The observed trend is that for a given mix, as the displacement rate increases, the value of shear stress at zero normal stress is also observed to increase with some mixes showing exceptions.

The final results obtained from flowability and rheological tests are tabulated in Table 4.

The slump flow values varied from $680 \mathrm{~mm}$ to $850 \mathrm{~mm}$ for different paste volume, aggregate volume and water content. The values of $\square_{\square \square}$ and $\square \square$ obtained experimentally are termed as relative, since values are not absolute. It can be observed, for a given cement and water content, with increase in $\mathrm{Vp}$, the yield stress decreases. This can be attributed to the fact that higher Vp leads to better reduced friction between aggregate particles which in turn reduces the inter-particle friction between the aggregates. Also, higher paste content means lower aggregate content; lower fraction of aggregates results in inter-particle spacing between the aggregates; thus reduced resistance to flow. Under low paste contents, the inter-particle friction dominates and results in higher relative yield stress. This phenomenon is clearly brought out by the concrete shear box test. It may be pointed out that the trend is similar to the results obtained with rheometers i.e., higher the flow, lower are the yield stress ( $\square \square \square$ and plastic viscosity ( $\square \square$. This could be attributed to particle interference (or friction) during shearing at low rates. These values are lower in rheometers due to high shear rates and concrete exhibits shear thinning behavior.

An important aspect is that the SCC is extremely sensitive to variations in mix proportioning and even slight variations can lead to wide variations in workability and there is a need to maintain equilibrium with the various constituents. The influence of various ingredients cannot be represented in simple empirical tests and rheological methods are more relevant for more advanced types of concrete, which are used today.

\section{CONCLUDING REMARKS}

The results of this experimental study have shown the effective use of newconcrete shear box in determining the rheological properties of fresh concrete (SCC) and can be an effective additional tool. The test is unique with consistent results and the values are obtained with normal stress and displacement rate at 'zero' values. The Bingham parameters obtained through these studies were termed as 'relative yield stress' and 'relative plastic viscosity'; partly due to higher than those reported in the literature as determined by rheometers with high shear rate.

\section{ACKNOWLEDGEMENT}

Research work reported here was supported by the Technical Education Quality Improvement Program [TEQIP-II] of the Ministry of Human Resources Development, Government of India through BMSCE and the authors sincerely acknowledge the same. The authors wish to appreciate and place on record the support given by Sri. Parthasarathy, Technical head, concrete laboratory and many UG and PG students while carrying out the experimental work.

\section{REFERENCES}

[1] Khayat K. H., Workability, testing and performance of self-consolidating concrete, American Concrete Institute Materials Journal, ACI, Vol. 96, No. 3, pp.346-353, 1999.

[2] American Concrete Institute Code ACI 237R-07 on Self-Consolidating Concrete, 2007.

[3] Koehler and Fowler, Summary of Concrete Workability Test Methods, International Centre for Aggregate Research, ICAR-Report-105, 2003.

[4] Zerbino, Barraga, Garcia, Agullo and R.Gettu, Workability tests and rheological parameters in selfcompacting concrete, Materials and Structures, 42, pp.947-960, 2009

[5] American Concrete Institute Code ACI: 238-1R.08 on Report on Measurements of Workability and Rheology of Fresh Concrete, 2008.

[6] Ferraris, Concrete Rheology: Knowledge and Challenges? $2^{\text {nd }}$ International Symposium on Advances Concrete through Science and Engineering11-13, September-2006, Quebec City, Canada, pp. 141-149.

[7] Larrard, Why Rheology Matters, Magazine of Concrete International, August, pp.79-81, 1999.

[8] British Standards, BS 5168:1975, Glossary of rheological terms, London, pp.18, 1975.

[9] Roger, Engineering Rheology, Oxford University Press Inc, New York, $2^{\text {nd }}$ Edition, ISBN-13:978-0198564737, 2002.

[10] Banfill, The Rheology of Fresh Cement and ConcreteA review, $11^{\text {th }}$ International Cement Chemistry Congress, Durban, pp.1-13, 2003.

[11] Ferraris, Measurement of Rheological Properties of High-Performance Concrete: State-of-the-art Report, National Institute of Standards and Technology, NISTIR 5869, Vol.104, September-October, pp.461478, 1999. 
[12] Koehler and Fowler, Development of a Portable rheometer for fresh Portland cement concrete, ICAR Report 105-3F, 2004.

[13] Ferraris, Measurement of Rheological Properties of Cement Paste, RILEM Proceedings, pp.333342, 1999.

[14] Larrard, Ferraris, and Sedran, Fresh Concrete: A Herschel-Bulkley Material, Materials and Structures, vol. 31, August-September, pp. 494498, 1998.

[15] Russels, Understanding the Rheology of Concrete, Woodhead Publishing Limited, ISBN 978-085709-028, 2012.

[16] Tattersall and Banfill, The Rheology of Fresh Concrete, Pitman Advanced Publishing, Boston, 1983.

[17] Ferraris and L.Brower, eds., Comparison of Concrete Rheometers: International Tests at MB (Cleveland OH, USA), National Institute of Standards and Technology-7154, October 2000.

[18] Andraz, Franci and Violeta, Rheological Parameters of Fresh Concrete - Comparison of Rheometers, GRADEVINAR 65-2, pp.99-109, 2013.

[19] K. Newman, Concrete systems, In: Holliday.L (Eds.), Composite materials, Amsterdam, Elsevier, Publishing co Ltd., pp.335-452, 1966.

[20] S.Girish and B.S. Santhosh, Concrete Shear Test: A new tool for determining rheological properties of fresh Portland cement concrete, Advance in Civil Engineering and Building Materials, pp.289293, 2011.

[21] S. Girish and B. S. Santhosh , Determination of Bingham Parameters of Fresh Portland cement Concrete Using Concrete Shear Box, Bonfring International Journal of Industrial Engineering and Management Science, Vol. 02, No 04 SPL, December,pp.84-90, 2012.

[22] S. Girish and B. S. Santhosh, G. S Vinay Kumar, and L. Shobha, Rheological Measurement of Fresh Portland Cement Concrete Using Direct Shear Box
Tests, Proceedings of the International Conference, Concrete in the Low Carbon Era, University of Dundee, Scotland, UK, pp. 287-302,2012.

[23] S. Girish and B.S. Santhosh, A New Methodology To Study The Rheological Properties of Fresh Portland Cement Concrete, International Journal of Earth Sciences and Engineering, Vol. 04, No. 06, pp.797800, 2013.

[24] S. Girish and B.S. Santhosh, A Unique Procedure for Finding the Rheological Properties of Fresh Portland Cement Concrete using Concrete Shear Tests, 1st International RILEM Conference on Rheology and processing of construction materials and $7^{\text {th }}$ International RILEM symposium on Self-Compacting Concrete, 2-4 ${ }^{\text {th }}$ September,Paris, France, pp.365$372,2013$.

[25] Girish. S and Ajay. N, Importance of rheological properties of fresh concrete - A review, The Indian Concrete Journal, September, Vol. 91, Issue 9, pp. 0917, 2017.

[26] S. Girish, Ajay. N, Girish Kumar S. and Hrushikesh M., A scientific approach to measure the workability of concrete using concrete shear box, The Indian Concrete Journal, March 2018, Vol. 92, Issue 3, pp. 24-35,2018.

[27] S. Girish, Jagadish. V and R. V. Ranganath, Volume fractions in self-compacting concrete-A review, Proceedings of the $5^{\text {th }}$ International RILEM Symposium on Self-Compacting Concrete, 3-5 September, Ghent, Belgium, pp.73-81, 2007.

[28] S. Girish, R. V. Ranganath and Jagadish Vengala, Influence of powder and paste on flow properties of SCC, Construction and Building Materials, volume 24, issue 12, December, pp.2481-2488, 2010.

[29] S. Girish, Importance of volume of paste on the compressive strength of SCC - A parameter to be considered in mix design, Indian Concrete Journal, April, pp. 51-62, 2017.

[30] EFNARC Guideline-2002 and 2005, Specification and Guidelines for Self-Compacting Concrete, UK, http://www.efnarc.org/. 


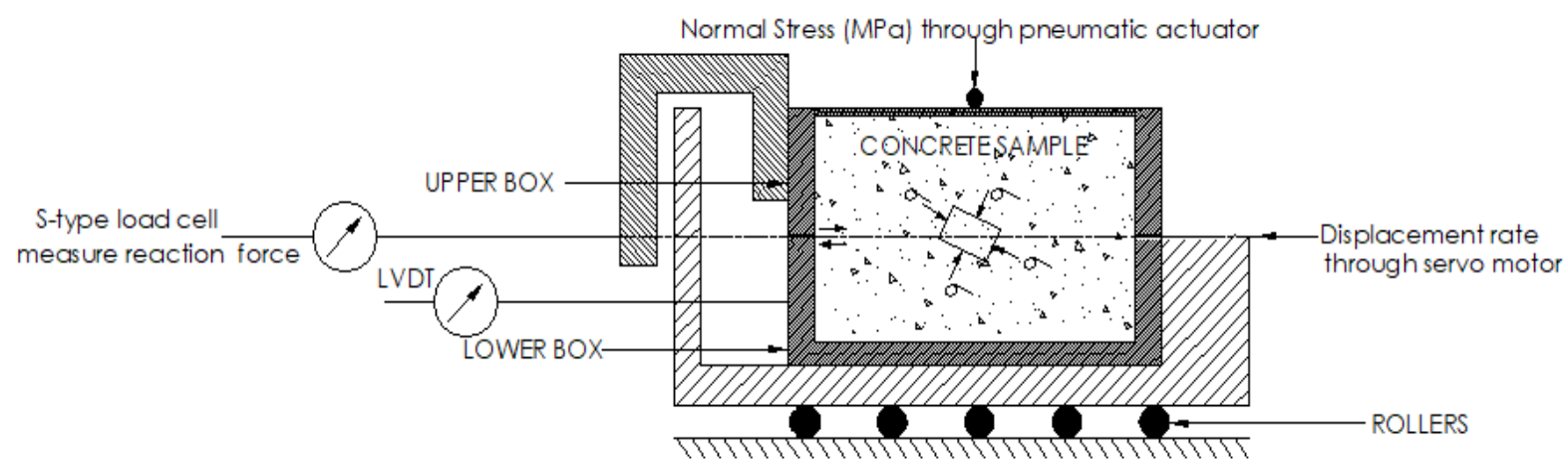

Fig 4: Schematic Representation of Concrete Shear box

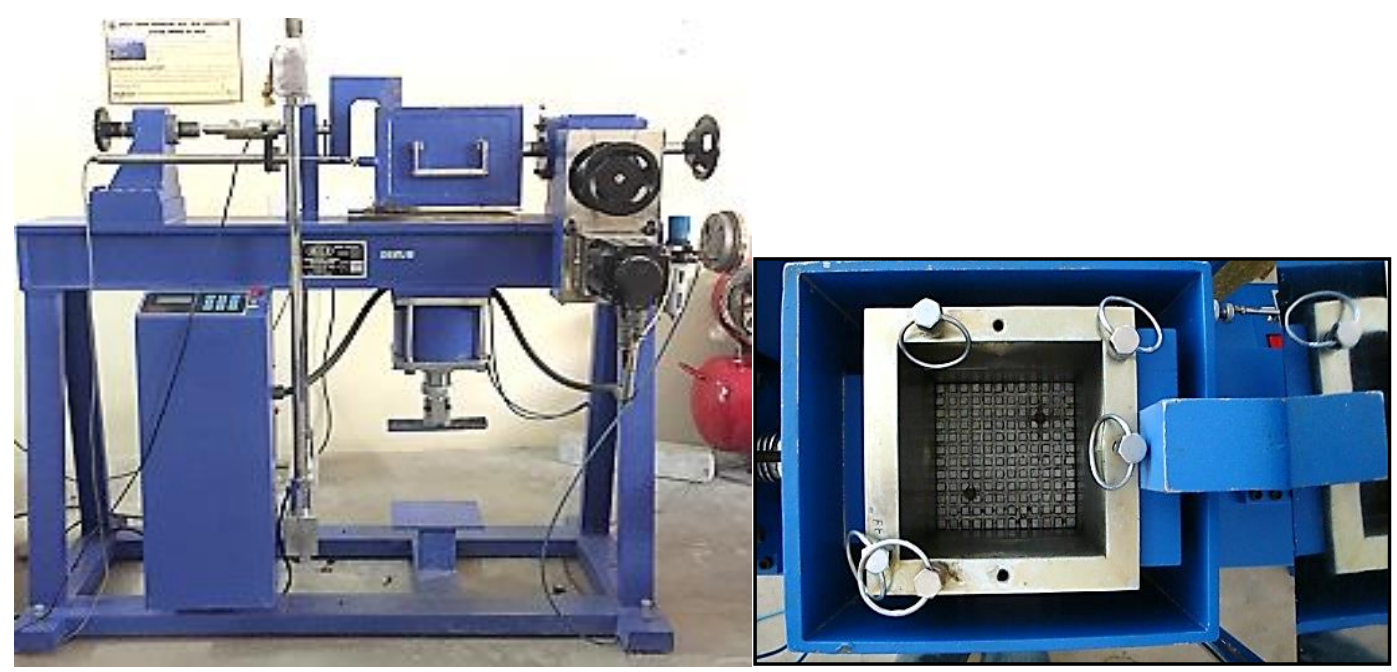

Fig 5: New Concrete Shear box (fabricated)
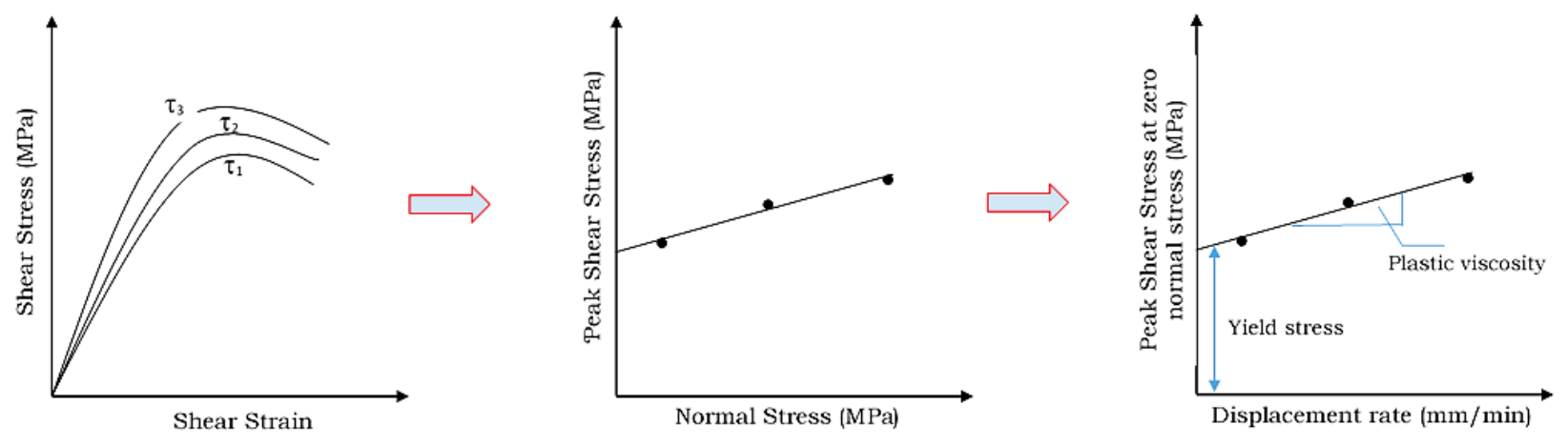

Bingham Parameters: Shear stress = Yield stress + Plastic viscosity * displacement rate

Fig 6: Unique Generalized Procedure for finding the Bingham Properties by using Concrete Shear Box [26] 


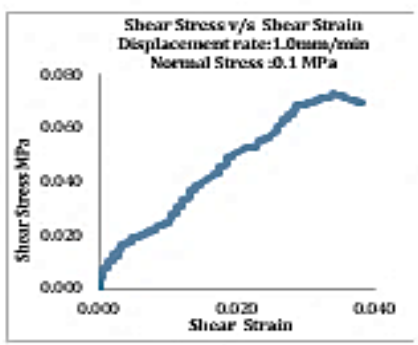

Fig (a)

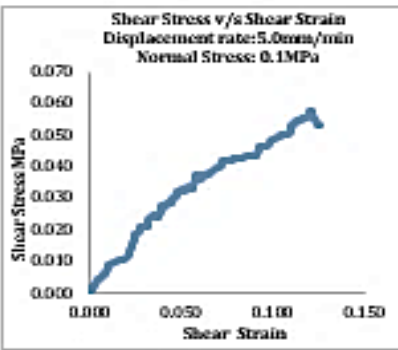

Fig (e)

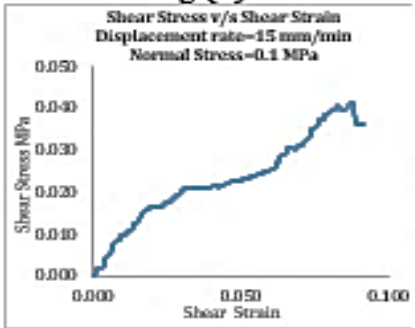

Fig (i)

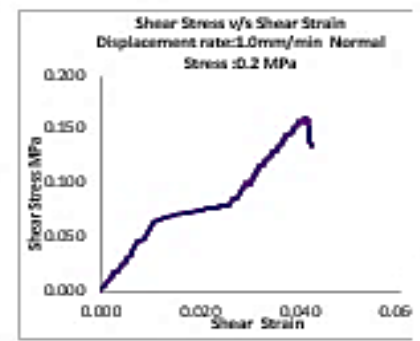

Fig (b)

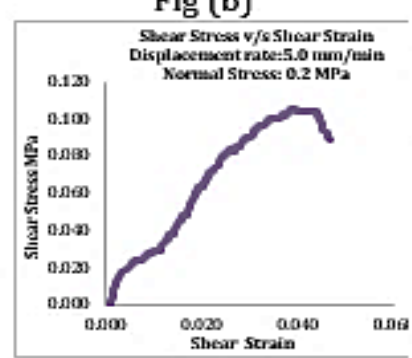

Fig (f)

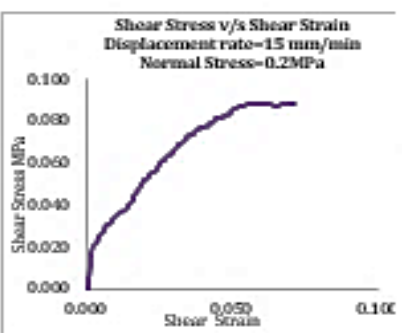

Fig (j)

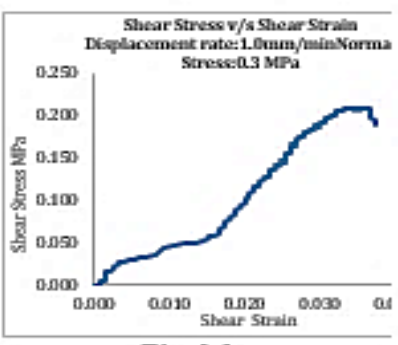

Fig (c)

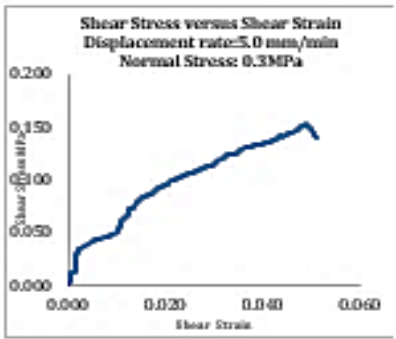

Fig (g)

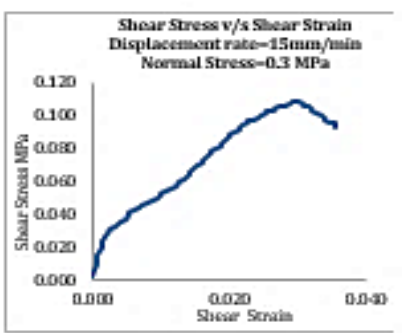

Fig (k)

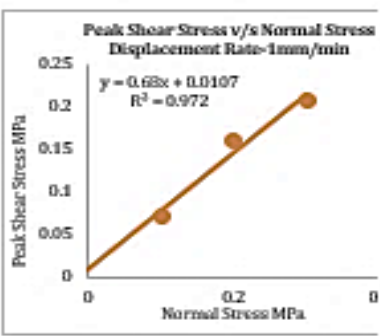

Fig (d)

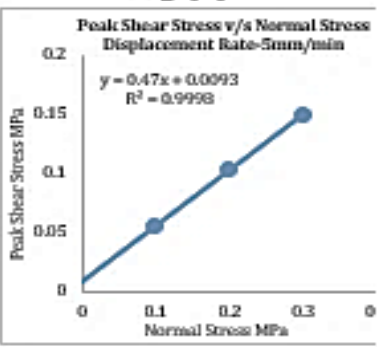

Fig (h)

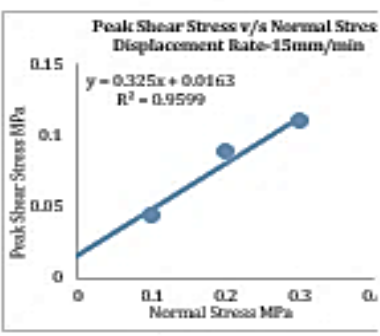

Fig (m)

Fig 7: Relation between Shear stress v/s Shear Strain and Peak Shear Stress v/s Zero Normal Stress (Mix-S1)

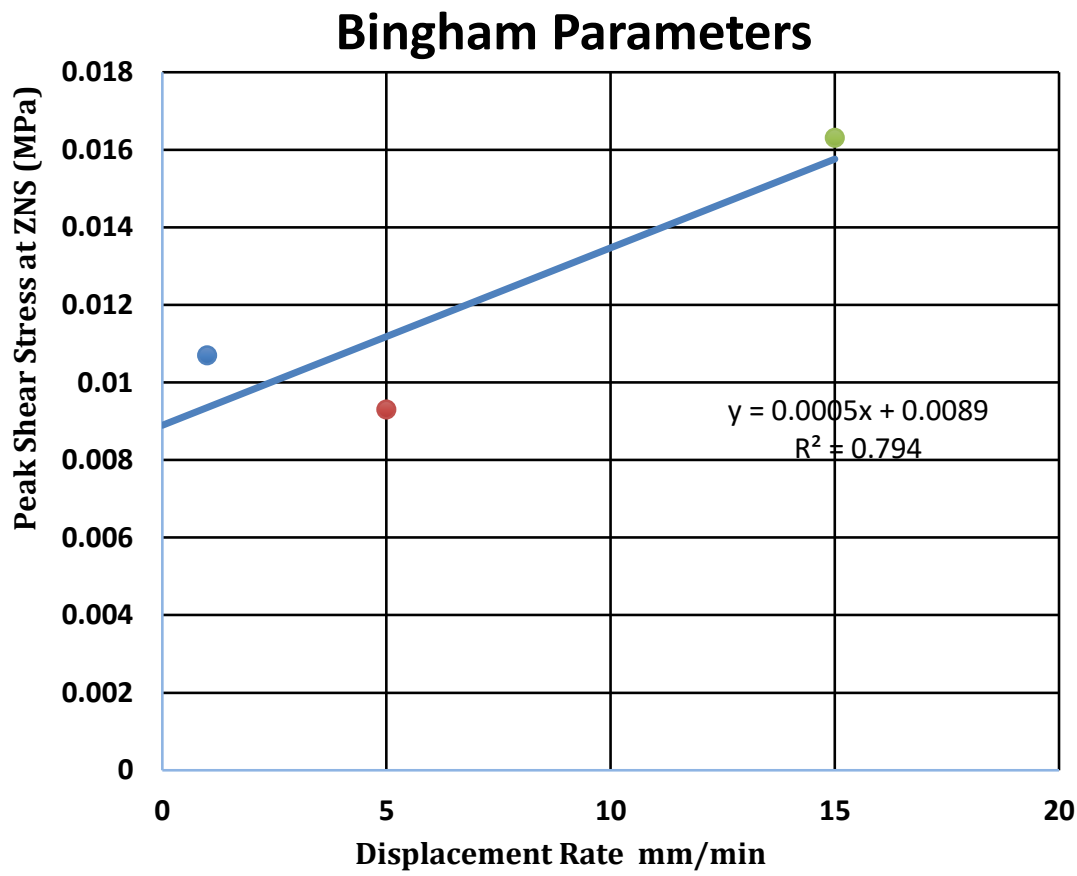


Fig 8: Bingham Parameters for Mix -S1

Table 1: Details of Mix Proportions

\begin{tabular}{|c|c|c|c|c|c|c|c|c|}
\hline Mix & $\begin{array}{l}\mathrm{Ce} \\
\left(\mathrm{kg} / \mathrm{m}^{3}\right)\end{array}$ & $\begin{array}{l}\text { FA } \\
\left(\mathrm{kg} / \mathrm{m}^{3}\right)\end{array}$ & $\begin{array}{l}\mathrm{CA} \\
\left(\mathrm{Kg} / \mathrm{m}^{3}\right)\end{array}$ & $\begin{array}{l}\text { GGBS } \\
\left(\mathrm{kg} / \mathrm{m}^{3}\right)\end{array}$ & $\begin{array}{l}\text { Water } \\
\left(1 \mathrm{t} / \mathrm{m}^{3}\right)\end{array}$ & $\begin{array}{l}\text { Powder } \\
\left(\mathrm{kg} / \mathrm{m}^{3}\right)\end{array}$ & $\begin{array}{l}\text { SP } \\
(\%)\end{array}$ & $\mathrm{Vp}$ \\
\hline S1 & \multirow[t]{3}{*}{300} & 945 & 654 & 279 & \multirow[t]{3}{*}{170} & 579 & 0.75 & 0.38 \\
\hline S2 & & 915 & 634 & 337 & & 637 & 0.75 & 0.40 \\
\hline S3 & & 885 & 613 & 395 & & 695 & 0.80 & 0.42 \\
\hline S4 & \multirow[t]{3}{*}{300} & 945 & 654 & 221 & \multirow[t]{3}{*}{190} & 521 & 0.45 & 0.38 \\
\hline S5 & & 915 & 634 & 279 & & 579 & 0.50 & 0.40 \\
\hline S6 & & 885 & 613 & 337 & & 637 & 0.55 & 0.42 \\
\hline S7 & \multirow[t]{3}{*}{450} & 945 & 654 & 136 & \multirow{3}{*}{170} & 586 & 0.65 & 0.38 \\
\hline S8 & & 915 & 634 & 194 & & 644 & 0.85 & 0.40 \\
\hline S9 & & 885 & 613 & 252 & & 702 & 0.95 & 0.42 \\
\hline S10 & \multirow[t]{3}{*}{450} & 945 & 654 & 78 & \multirow{3}{*}{190} & 528 & 0.35 & 0.38 \\
\hline S11 & & 915 & 634 & 136 & & 586 & 0.40 & 0.40 \\
\hline S12 & & 885 & 613 & 194 & & 644 & 0.55 & 0.42 \\
\hline
\end{tabular}

Note: Ce-cement; FA-fine aggregate; CA-coarse aggregate; SP-superplasticizer; Vp-volume of paste

Table 2: Peak Shear Stress values

\begin{tabular}{|c|c|c|c|c|c|c|c|c|c|c|c|c|c|}
\hline \multirow{2}{*}{$\begin{array}{l}\text { Disp. } \\
\text { Rate } \\
\mathrm{mm} / \mathrm{min}\end{array}$} & \multirow{2}{*}{$\begin{array}{l}\text { Norma } \\
1 \text { Stress } \\
(\mathrm{MPa})\end{array}$} & \multicolumn{12}{|c|}{ Peak shear stress (MPa) } \\
\hline & & S1 & S2 & S3 & S4 & S5 & S6 & S7 & S8 & S9 & S10 & S11 & S12 \\
\hline \multirow[t]{3}{*}{1} & $\mathbf{0 . 1 0}$ & $\begin{array}{l}0.07 \\
2\end{array}$ & $\begin{array}{l}0.06 \\
0\end{array}$ & $\begin{array}{l}0.08 \\
4\end{array}$ & $\begin{array}{l}0.11 \\
2\end{array}$ & $\begin{array}{l}0.10 \\
6\end{array}$ & $\begin{array}{l}0.09 \\
0\end{array}$ & $\begin{array}{l}0.12 \\
3\end{array}$ & $\begin{array}{l}0.06 \\
6\end{array}$ & $\begin{array}{l}0.03 \\
0\end{array}$ & $\begin{array}{l}0.08 \\
0\end{array}$ & $\begin{array}{l}0.08 \\
0\end{array}$ & $\begin{array}{l}0.07 \\
5\end{array}$ \\
\hline & 0.20 & $\begin{array}{l}0.16 \\
0 \\
\end{array}$ & $\begin{array}{l}0.08 \\
9 \\
\end{array}$ & $\begin{array}{l}0.15 \\
0 \\
\end{array}$ & $\begin{array}{l}0.18 \\
7 \\
\end{array}$ & $\begin{array}{l}0.20 \\
6 \\
\end{array}$ & $\begin{array}{l}0.16 \\
4 \\
\end{array}$ & $\begin{array}{l}0.16 \\
0 \\
\end{array}$ & $\begin{array}{l}0.16 \\
3 \\
\end{array}$ & $\begin{array}{l}0.10 \\
0 \\
\end{array}$ & $\begin{array}{l}0.16 \\
0 \\
\end{array}$ & $\begin{array}{l}0.22 \\
0 \\
\end{array}$ & $\begin{array}{l}0.11 \\
6 \\
\end{array}$ \\
\hline & $\mathbf{0 . 3 0}$ & $\begin{array}{l}0.20 \\
8 \\
\end{array}$ & $\begin{array}{l}0.16 \\
0 \\
\end{array}$ & $\begin{array}{l}0.25 \\
0 \\
\end{array}$ & $\begin{array}{l}0.30 \\
0 \\
\end{array}$ & $\begin{array}{l}0.30 \\
0 \\
\end{array}$ & $\begin{array}{l}0.26 \\
0 \\
\end{array}$ & $\begin{array}{l}0.32 \\
0 \\
\end{array}$ & $\begin{array}{l}0.24 \\
0 \\
\end{array}$ & $\begin{array}{l}0.25 \\
0 \\
\end{array}$ & $\begin{array}{l}0.20 \\
0 \\
\end{array}$ & $\begin{array}{l}0.25 \\
0 \\
\end{array}$ & $\begin{array}{l}0.20 \\
0 \\
\end{array}$ \\
\hline \multirow[t]{3}{*}{5} & $\mathbf{0 . 1 0}$ & $\begin{array}{l}0.05 \\
6\end{array}$ & $\begin{array}{l}0.05 \\
6\end{array}$ & $\begin{array}{l}0.06 \\
6\end{array}$ & $\begin{array}{l}0.06 \\
7\end{array}$ & $\begin{array}{l}0.07 \\
8\end{array}$ & $\begin{array}{l}0.06 \\
5\end{array}$ & $\begin{array}{l}0.06 \\
0\end{array}$ & $\begin{array}{l}0.04 \\
6\end{array}$ & $\begin{array}{l}0.04 \\
1\end{array}$ & $\begin{array}{l}0.07 \\
0\end{array}$ & $\begin{array}{l}0.06 \\
3\end{array}$ & $\begin{array}{l}0.06 \\
0\end{array}$ \\
\hline & 0.20 & $\begin{array}{l}0.10 \\
4\end{array}$ & $\begin{array}{l}0.12 \\
8\end{array}$ & $\begin{array}{l}0.11 \\
7 \\
\end{array}$ & $\begin{array}{l}0.17 \\
7 \\
\end{array}$ & $\begin{array}{l}0.13 \\
1 \\
\end{array}$ & $\begin{array}{l}0.12 \\
1 \\
\end{array}$ & $\begin{array}{l}0.11 \\
0 \\
\end{array}$ & $\begin{array}{l}0.10 \\
0 \\
\end{array}$ & $\begin{array}{l}0.06 \\
2\end{array}$ & $\begin{array}{l}0.14 \\
0 \\
\end{array}$ & $\begin{array}{l}0.15 \\
8\end{array}$ & $\begin{array}{l}0.10 \\
0 \\
\end{array}$ \\
\hline & $\mathbf{0 . 3 0}$ & $\begin{array}{l}0.15 \\
0\end{array}$ & $\begin{array}{l}0.15 \\
2\end{array}$ & $\begin{array}{l}0.15 \\
3\end{array}$ & $\begin{array}{l}0.20 \\
0\end{array}$ & $\begin{array}{l}0.19 \\
7 \\
\end{array}$ & $\begin{array}{l}0.14 \\
7 \\
\end{array}$ & $\begin{array}{l}0.15 \\
0 \\
\end{array}$ & $\begin{array}{l}0.14 \\
0\end{array}$ & $\begin{array}{l}0.11 \\
0\end{array}$ & $\begin{array}{l}0.16 \\
5\end{array}$ & $\begin{array}{l}0.17 \\
8\end{array}$ & $\begin{array}{l}0.13 \\
5\end{array}$ \\
\hline \multirow[t]{3}{*}{15} & $\mathbf{0 . 1 0}$ & $\begin{array}{l}0.04 \\
5 \\
\end{array}$ & $\begin{array}{l}0.05 \\
0 \\
\end{array}$ & $\begin{array}{l}0.06 \\
9 \\
\end{array}$ & $\begin{array}{l}0.07 \\
5 \\
\end{array}$ & $\begin{array}{l}0.07 \\
0 \\
\end{array}$ & $\begin{array}{l}0.05 \\
4 \\
\end{array}$ & $\begin{array}{l}0.05 \\
5 \\
\end{array}$ & $\begin{array}{l}0.05 \\
9 \\
\end{array}$ & $\begin{array}{l}0.03 \\
0 \\
\end{array}$ & $\begin{array}{l}0.06 \\
0\end{array}$ & $\begin{array}{l}0.05 \\
1 \\
\end{array}$ & $\begin{array}{l}0.04 \\
9 \\
\end{array}$ \\
\hline & 0.20 & $\begin{array}{l}0.08 \\
9\end{array}$ & $\begin{array}{l}0.12 \\
6 \\
\end{array}$ & $\begin{array}{l}0.08 \\
8\end{array}$ & $\begin{array}{l}0.19 \\
0\end{array}$ & $\begin{array}{l}0.12 \\
7 \\
\end{array}$ & $\begin{array}{l}0.11 \\
0 \\
\end{array}$ & $\begin{array}{l}0.10 \\
0\end{array}$ & $\begin{array}{l}0.07 \\
0\end{array}$ & $\begin{array}{l}0.05 \\
0 \\
\end{array}$ & $\begin{array}{l}0.10 \\
0\end{array}$ & $\begin{array}{l}0.10 \\
8\end{array}$ & $\begin{array}{l}0.08 \\
5 \\
\end{array}$ \\
\hline & $\mathbf{0 . 3 0}$ & $\begin{array}{l}0.11 \\
0\end{array}$ & $\begin{array}{l}0.13 \\
6\end{array}$ & $\begin{array}{l}0.11 \\
0\end{array}$ & $\begin{array}{l}0.21 \\
8\end{array}$ & $\begin{array}{l}0.15 \\
4\end{array}$ & $\begin{array}{l}0.10 \\
5\end{array}$ & $\begin{array}{l}0.13 \\
0\end{array}$ & $\begin{array}{l}0.15 \\
0\end{array}$ & $\begin{array}{l}0.08 \\
0\end{array}$ & $\begin{array}{l}0.12 \\
0\end{array}$ & $\begin{array}{l}0.12 \\
0\end{array}$ & $\begin{array}{l}0.09 \\
5\end{array}$ \\
\hline
\end{tabular}

Table 3: Shear Stress at Zero Normal Stresses (ZNS)

\begin{tabular}{|c|c|c|c|c|c|c|c|c|c|c|c|c|}
\hline \multirow{2}{*}{$\begin{array}{l}\text { Disp. } \\
\text { Rate } \\
\mathrm{mm} / \mathrm{min}\end{array}$} & \multicolumn{12}{|c|}{ Peak shear stress at ZNS (MPa) } \\
\hline & S1 & S2 & S3 & S4 & S5 & S6 & S7 & S8 & S9 & S10 & S11 & S12 \\
\hline 1 & $\begin{array}{l}0.010 \\
7 \\
\end{array}$ & $\begin{array}{l}0 .(1 \\
3\end{array}$ & 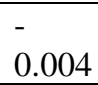 & $\begin{array}{l}0.01 \\
2\end{array}$ & $\begin{array}{l}0.01 \\
0\end{array}$ & $\begin{array}{l}0.00 \\
1\end{array}$ & $\begin{array}{l}0.00 \\
4\end{array}$ & $\overline{0}-\overline{0}$ & -0.010 & $\begin{array}{l}0.026 \\
7 \\
\end{array}$ & $\begin{array}{l}0.013 \\
3 \\
\end{array}$ & $\begin{array}{l}0.005 \\
3 \\
\end{array}$ \\
\hline 5 & $\begin{array}{l}0.009 \\
3 \\
\end{array}$ & $\begin{array}{l}0.01 \\
6 \\
\end{array}$ & 0.025 & $\begin{array}{l}0.01 \\
5 \\
\end{array}$ & $\begin{array}{l}0.01 \\
6 \\
\end{array}$ & $\begin{array}{l}0.02 \\
9\end{array}$ & $\begin{array}{l}0.01 \\
6\end{array}$ & 0.001 & 0.002 & 0.030 & $\begin{array}{l}0.018 \\
0 \\
\end{array}$ & $\begin{array}{l}0.023 \\
5 \\
\end{array}$ \\
\hline 15 & $\begin{array}{l}0.016 \\
3 \\
\end{array}$ & $\begin{array}{l}0.01 \\
8 \\
\end{array}$ & 0.048 & $\begin{array}{l}0.01 \\
8 \\
\end{array}$ & $\begin{array}{l}0.03 \\
3 \\
\end{array}$ & $\begin{array}{l}0.03 \\
8 \\
\end{array}$ & $\begin{array}{l}0.02 \\
0 \\
\end{array}$ & 0.002 & 0.0025 & $\begin{array}{l}0.033 \\
3 \\
\end{array}$ & $\begin{array}{l}0.024 \\
0 \\
\end{array}$ & $\begin{array}{l}0.030 \\
3 \\
\end{array}$ \\
\hline
\end{tabular}


Table 4: Fresh Properties of SCC mixes along with rheological values

\begin{tabular}{|c|c|c|c|c|c|c|c|c|c|c|}
\hline \multirow[t]{2}{*}{ Mix } & \multirow{2}{*}{$\begin{array}{l}\text { Cement } \\
\left(\mathrm{kg} / \mathrm{m}^{3}\right)\end{array}$} & \multirow{2}{*}{$\begin{array}{l}\text { Water } \\
\left(1 \mathrm{l} / \mathrm{m}^{3}\right)\end{array}$} & \multirow[t]{2}{*}{$\mathrm{Vp}$} & \multirow{2}{*}{$\begin{array}{l}\text { Slump } \\
(\mathrm{mm})\end{array}$} & \multirow{2}{*}{$\begin{array}{l}\mathrm{T}_{500 \mathrm{~mm}} \\
(\mathrm{~s})\end{array}$} & \multicolumn{2}{|c|}{ V-funnel (s) } & \multirow{2}{*}{$\begin{array}{l}\text { J-ring } \\
(\mathrm{mm})\end{array}$} & \multirow{2}{*}{$\begin{array}{l}\text { Yield Stress } \\
(\mathrm{Pa})\end{array}$} & \multirow{2}{*}{$\begin{array}{ll}\text { Plastic } & \text { viscosity } \\
(\mathrm{MPa}-\mathrm{s}) & \end{array}$} \\
\hline & & & & & & V0 & V5 & & & \\
\hline S1 & \multirow[t]{3}{*}{300} & \multirow[t]{3}{*}{170} & 0.38 & 750 & 4.7 & 8.0 & 8.0 & 4.0 & 8900 & 4.5 \\
\hline S2 & & & 0.40 & 770 & 3.8 & 8.5 & 8.9 & 3.0 & 6000 & 8.1 \\
\hline S3 & & & 0.42 & 850 & 3.5 & 10.0 & 10.8 & 5.0 & 3600 & 3.5 \\
\hline S4 & \multirow[t]{3}{*}{300} & \multirow[t]{3}{*}{190} & 0.38 & 720 & 2.0 & 5.0 & 5.0 & 10.0 & 12200 & 3.6 \\
\hline S5 & & & 0.40 & 730 & 2.2 & 5.2 & 5.5 & 3.0 & 8200 & 14.6 \\
\hline S6 & & & 0.42 & 750 & 2.5 & 5.5 & 6.0 & 10.0 & 6600 & 20.7 \\
\hline S7 & \multirow[t]{3}{*}{450} & \multirow[t]{3}{*}{170} & 0.38 & 690 & 3.2 & 8.0 & 8.5 & 0.0 & 6700 & 9.0 \\
\hline S8 & & & 0.40 & 800 & 3.0 & 8.0 & 9.0 & 0.0 & 4300 & 6.3 \\
\hline S9 & & & 0.42 & 850 & 2.8 & 8.5 & 10.0 & 5.0 & 3300 & 6.0 \\
\hline S10 & \multirow[t]{3}{*}{450} & \multirow[t]{3}{*}{190} & 0.38 & 680 & 2.7 & 7.0 & 7.2 & 5.0 & 26900 & 3.6 \\
\hline S11 & & & 0.40 & 700 & 2.3 & 7.4 & 7.8 & 5.0 & 13300 & 6.3 \\
\hline S12 & & & 0.42 & 725 & 2.4 & 8.5 & 8.8 & 5.0 & 8700 & 14.4 \\
\hline
\end{tabular}

